\title{
PENGARUH TERAPI RELAKSASI OTOT PROGRESIF TERHADAP KEKUATAN OTOT DAN KUALITAS TIDUR LANJUT USIA
}

\author{
Abdul Muhith ${ }^{1)}$, Teguh Herlambang ${ }^{2)}$, Atika Fatmawati ${ }^{3)}$, Dyah Siwi Hety ${ }^{4)}$, \\ I Wayan Surya Merta ${ }^{5}$ \\ ${ }^{1), 2)}$ Universitas Nahdlatul Ulama Surabaya (UNUSA) \\ 3), 4), 5) STIKes Majapahit Mojokerto Indonesia \\ E-mail : abdulmuhith@,unusa.ac.id
}

\begin{abstract}
Physiological changes in the elderly can cause a change in the neural system that is a disorder towards sleep quality while changes in the musculoskeletal system are the occurrence of muscle strength decline. Progressive Muscle Relaxation Therapy is a therapy which can improve sleep quality and muscle strength. The purpose of this research is to analyze the effect of progressive muscle relaxation therapy towards muscle strength and sleep quality of the elderly at House Technical Implementation. The research type used is quasi-experiment design with pretest and posttest nonequivalent control group design. The population in this research were all elderly as many as 40 elderly people. The sampling technique used was Total Sampling which was then divided into intervention group which consists of 20 respondents and control group which consists of 20 respondents. The measurement tool used was PSQI (Pittsburgh Sleep Quality Index) questionnaire for sleep quality and the MMT (Manual Muscle Testing) observation sheet for muscle strength. The data were analyzed using Paired T-test and Independent T-test. Based on Paired T-test, it was obtained that $p$ value $=0.000(p<0,05)$ for muscle strength and $p$ value $=0,000(p<0,05)$ for sleep quality which indicated significant difference. While according to the independent $T$-test results, it was obtained that $p$ value $=$ $0.000(p<0.05)$ which indicated that there was an effect of progressive muscle relaxation therapy towards muscle strength and sleep quality of elderly people at House Technical Implementation. Therapy can be used as an alternative method for elderly people to improve muscle strength and sleep quality so that nurses working in the elderly special service order can integrate this therapy in the nursing care.
\end{abstract}

Keywords : The elderly; sleep quality; muscle strength; progressive muscle relaxation therapy

\begin{abstract}
ABSTRAK
Perubahan aspek fisiologis pada lansia dapat menyebabkan adanya perubahan pada sistem persarafan yaitu gangguan terhadap kualitas tidur sedangkan perubahan pada sistem muskuloskeletal yaitu terjadinya penurunan kekuatan otot. Terapi Relaksasi Otot Progresif merupakan terapi yang dapat meningkatkan kualitas tidur dan kekuatan otot. Tujuan
\end{abstract}

Cara mengutip: Muhith, Abdull., Herlambang, Teguh., Fatmawati, Atika., Hety, D. Siwi., Merta, I-Wayan S. (2020). Pengaruh terapi Relaksasi Otot Progresif Terhadap Kekuatan Otot dan Kualitas Tidur Lanjut Usia. Care:Jurnal Ilmiah Ilmu Kesehatan, 8(2), 306-314 
penelitian ini adalah untuk menganalisis pengaruh terapi relaksasi otot progresif terhadap kekuatan otot dan kualitas tidur lanjut usia.Jenis penelitian yang digunakan adalah penelitian quasy experiment design dengan rancangan pretest and posttest nonequivalent control group. Populasi dalam penelitian ini semua lanjut usia sebanyak 40 lanjut usia. Teknik sampling yang digunakan adalah Total Sampling yang kemudian dibagi menjadi kelompok intervensi sebanyak 20 responden dan kelompokkontrol sebanyak 20 responden.Alatukur yang digunakanadalahkuesioner PSQI (Pittsburgh Sleep Quality Indeks) untuk kualitas tidur dan lembar observasi MMT (Manual Muscle Testing) untuk kekuatan otot. Data dianalisis menggunakan uji Paired T-test dan uji Independent T-test. Berdasarkan uji Paired T-test didapatkan hasil $p$ value $=0,000(p<0,05)$ untuk kekuatan otot dan $p$ value $=0,000(p<0,05)$ untuk kualitas tidur yang menunjukan adanya perbedaan yang signifikan. Sedangkan pada uji Independent T-test diperoleh hasil $p$ value $=0,000(p<0,05)$ yang menunjukan ada pengaruh terapi relaksasi otot progresif terhadap kekuatan otot dan kualitas tidur lanjut usia. Terapi ini dapat dijadikan sebagai salah satu metode alternatif bagi lanjut usia untuk meningkatkan kekuatan otot dan kualitas tidur, sehingga perawat yang bekerja di tatanan pelayanan khusus lansia mengintegrasikan terapi ini ke dalam asuhan keperawatan.

Kata Kunci : Lansia; kualitas tidur; kekuatan otot; terapi relaksasi otot progresif.

\section{PENDAHULUAN}

Proses penuaan dalam perjalanan hidup manusia merupakan suatu hal wajar yang akan dialami semua orang dan pada usia di atas 60 tahun terjadi. Hal ini akan menimbulkan terjadinya perubahan terhadap aspek fisiologis, aspek mental, aspek sosial, aspek ekonomi, dan aspek psikologis. Perubahan dari aspek fisiologis menyebabkan adanya perubahan fisik pada lanjut usia diantaranya perubahan sistem persarafan dan sistem muskuloskeletal (Muhith, 2016).

Hasil studi pendahuluan di Panti Werdha Mojopahit Mojokerto terhadap 15 responden diperoleh data 11 responden tidak bisa tidur karena merasa kepanasan dan merasa kesakitan dan tidak dapat tidur kembali, dan dari 11 responden tersebut 7 responden berjenis kelamin laki-laki dan 4 responden berjenis kelamin perempuan, sedangkan 4 responden bisa tidur tanpa ada masalah dalam tidurnya. Pengukuran derajat kekuatan otot terhadap 15 responden diperoleh data 5 responden dengan skala 2, 4 responden diperoleh data dengan skala 3, 4 responden diperoleh data dengan skala 4, 2 responden diperoleh data dengan skala 5.

Penurunan kekuatan otot pada lansia terjadi karena adanya perubahan struktur otot akibat penuaan. Bentuk - bentuk perubahan struktur otot tersebut berupa penurunan jumlah dan ukuran serabut 
otot, atropi pada beberapa serabut otot dan hipertropi (Muhith A., 2016). Kualitas tidur sangat berpengaruh terhadap kesehatan manusia, karena kebugaran disaat bangun tidur ditentukan oleh kualitas tidur sepanjang malam. Kekurangan tidur menyebabkan rasa ngantuk pada siang hari, mengalami gangguan memori, depresi, gangguan kognitif, stres, sering terjatuh hingga penurunan kualitas hidup (Hidayat \& Ulyah, 2015). Terapi relaksasi otot progresif termasuk terapi paling murah sampai saat ini karena tidak memerlukan imajinasi, ketekunan atau sugesti, tidak ada efek samping, dan mudah untuk dilakukan (Fitriani, 2017). Tujuan penelitian ini adalah untuk menganalisis pengaruh terapi relaksasi otot progresif terhadap kekuatan otot dan kualitas tidur lanjut usia.

\section{METODE PENELITIAN}

Penelitian ini menggunakan jenis penelitian quasy experiment design menggunakan rancangan pretest and posttest nonequivalent control group. Populasi adalah semua lanjut usia di Panti Werdha Mojopahit Mojokerto sebanyak 40 lanjut usia dengan teknik Total Samping yang dibagi ke dalam kelompok kontrol sebanyak 20 responden dan kelompok intervensi sebanyak 20 responden. Alat ukur yang digunakan adalah lembar observasi MMT (Manual Muscle Testing) untuk kekuatan otot dan kuesioner PSQI (Pittsburgh Sleep Quality Index) untuk kualitas tidur.

\section{HASIL}

Tabel 1. Kekuatan Otot sebelum dan sesudah dilakukan aktivitas biasa tanpa terapi relaksasi otot progresif pada kelompok kontrol

\begin{tabular}{lcccc}
\multicolumn{1}{c}{ Skala Kekuatan Otot } & \multicolumn{2}{c}{ Pre Test } & \multicolumn{2}{c}{ Post Test } \\
\cline { 2 - 5 } & $\mathrm{f}$ & $(\%)$ & $\mathrm{f}$ & $(\%)$ \\
\hline 0: Tidak ada gerakan otot sama sekali. & 0 & 0 & 0 & 0 \\
\hline $\begin{array}{l}\text { 1: Ada kontraksi saat palpasi tetapi tidak ada gerakan } \\
\text { yang terlihat. }\end{array}$ & 2 & $10 \%$ & 0 & 0 \\
\hline 2: Ada gerakan tetapi tidak dapat melawan gravitasi & 8 & $40 \%$ & 7 & $35 \%$ \\
\hline 3: Dapat bergerak melawan gravitasi & 8 & $40 \%$ & 10 & $50 \%$ \\
\hline $\begin{array}{l}\text { 4: Dapat bergerak melawan tahanan pemeriksa tetapi } \\
\text { masih lemah. }\end{array}$ & 2 & $10 \%$ & 3 & $15 \%$ \\
\hline $\begin{array}{c}\text { 5: Dapat bergerak dan melawan tahanan pemeriksa } \\
\text { dengan kekuatan penuh. }\end{array}$ & 0 & 0 & 0 & 0 \\
\hline Total & 20 & $100 \%$ & 20 & $100 \%$ \\
\hline Uji Paired T-test & & $\alpha=0,05 p=0,110$ &
\end{tabular}

Berdasarkan Tabel 1 menunjukan bahwa pada saat pre test hampir setengahnya responden mengalami ada gerakan tetapi tidak dapat melawan gravitasi $(40 \%)$ dan 
dapat bergerak melawan gravitasi (40\%), diberikan post test menunjukan bahwa sedangkan setelah dilakukan aktivitas setengahnya responden dapat bergerak biasa tanpa terapi relaksasi otot progresif melawan gravitasi sebanyak (50\%).

Tabel 2. Kekuatan Otot sebelum dan sesudah dilakukan terapi relaksasi otot progresif pada kelompok intervensi

\begin{tabular}{lcccc}
\multicolumn{1}{c}{ Skala Kekuatan Otot } & \multicolumn{2}{c}{ Pre Test } & \multicolumn{2}{c}{ Post Test } \\
\cline { 2 - 5 } & $\mathrm{f}$ & $(\%)$ & $\mathrm{f}$ & $(\%)$ \\
\hline 0: Tidak ada gerakan otot sama sekali. & 0 & 0 & 0 & 0 \\
\hline $\begin{array}{l}\text { 1: Ada kontraksi saat palpasi tetapi tidak ada gerakan } \\
\text { yang terlihat. }\end{array}$ & 0 & 0 & 0 & 0 \\
\hline 2: Ada gerakan tetapi tidak dapat melawan gravitasi. & 4 & $20 \%$ & 0 & 0 \\
\hline 3: Dapat bergerak melawan gravitasi. & 9 & $45 \%$ & 0 & 0 \\
\hline $4: \begin{array}{c}\text { Dapat bergerak melawan tahanan pemeriksa tetapi } \\
\text { masih lemah. }\end{array}$ & 7 & $35 \%$ & 8 & $40 \%$ \\
\hline $5: \begin{array}{l}\text { Dapat bergerak dan melawan tahanan pemeriksa } \\
\text { dengan kekuatan penuh. }\end{array}$ & 0 & 0 & 12 & $60 \%$ \\
\hline Total & 20 & $100 \%$ & 20 & $100 \%$ \\
\hline Uji Paired T-test & & $\alpha=0,05 p=0,000$ &
\end{tabular}

Berdasarkan Tabel 2 menunjukan bahwa pada saat pre test hampir setengahnya responden mengalami dapat bergerak melawan gravitasi (45\%), sedangkan setelah dilakukan terapi relaksasi otot progresif diberikan post test menunjukan bahwa sebagian besar responden mengalami dapat bergerak dan melawan tahanan pemeriksa dengan kekuatan penuh $(60 \%)$.

Tabel 3. Kualitas tidur sebelum dan sesudah dilakukan aktivitas biasa tanpa terapi relaksasi otot progresif pada kelompok kontrol.

\begin{tabular}{ccccc}
\multirow{2}{*}{ Kualitas Tidur } & \multicolumn{2}{c}{ Pre Test } & \multicolumn{2}{c}{ Post Test } \\
\cline { 2 - 5 } & $\mathrm{f}$ & $(\%)$ & $\mathrm{f}$ & $(\%)$ \\
\hline$<5:$ kulitas tidur baik & 1 & $5 \%$ & 2 & $10 \%$ \\
\hline$\geq 5:$ kualitas tidur buruk & 19 & $95 \%$ & 18 & $90 \%$ \\
\hline Total & 20 & $100 \%$ & 20 & $100 \%$ \\
\hline Uji Paired T-test & & $\alpha=0,05 p=0,126$ &
\end{tabular}

Tabel 4. Kualitas tidur sebelum dan sesudah dilakukan terapi relaksasi otot progresif pada kelompok kontrol.

\begin{tabular}{ccccc}
\multirow{2}{*}{ Kualitas Tidur } & \multicolumn{2}{c}{ Pre Test } & \multicolumn{2}{c}{ Post Test } \\
\cline { 2 - 5 } & F & $\begin{array}{c}\text { Persentase } \\
(\%)\end{array}$ & F & $\begin{array}{c}\text { Persentase } \\
(\%)\end{array}$ \\
\hline$<5:$ kulitas tidur baik & 0 & 0 & 16 & $80 \%$ \\
\hline$\geq 5:$ kualitas tidur buruk & 20 & $100 \%$ & 4 & $20 \%$ \\
\hline Total & 20 & $100 \%$ & 20 & $100 \%$ \\
\hline Uji Paired T-test & \multicolumn{3}{c}{$\alpha=0,05 p=0,000$}
\end{tabular}

Berdasarkan Tabel 3 menunjukan bahwa pada saat pre test hampir seluruhnya responden mengalami kualitas tidur buruk sebanyak 19 responden (95\%), 
sedangkan setelah dilakukan aktivitas biasa tanpa terapi relaksasi otot progresif diberikan post test menunjukan bahwa hampir seluruhnya mengalami kualitas tidur buruk sebanyak 18 responden $(90 \%)$.
Berdasarkan Tabel 4 menunjukan bahwa pada saat pre test seluruh responden mengalami kualitas tidur buruk sebanyak 20 responden (100\%), sedangkan setelah dilakukan terapi relaksasi otot progresif diberikan post test menunjukan bahwa hampir seluruhnya mengalami kualitas tidur baik sebanyak 16 responden (80\%).

Tabel 5. Pengaruh terapi relaksasi otot progresif terhadap kekuatan otot dan kualitas tidur lanjut usia

\begin{tabular}{lccc}
\multirow{2}{*}{ Kelompok } & \multicolumn{2}{c}{ Rata-rata (SD) } & \multirow{2}{*}{$\boldsymbol{P}$ value } \\
\cline { 2 - 3 } & Pre Intervensi & Post Intervensi & \\
\hline Kontrol $(\mathrm{n}=20)$ & $2,50(0,827)$ & $2,80(0,696)$ & $0,110^{\mathrm{a}}$ \\
\hline Intervensi $(\mathrm{n}=20)$ & $3,15(0,745)$ & $4,60(0,503)$ & $0,000^{\mathrm{b}}$ \\
\hline $\boldsymbol{P}_{\text {value }}$ & $0,013^{\mathrm{c}}$ & $0,000^{\mathrm{d}}$ & P value $<0,05$ \\
\hline Kontrol $(\mathrm{n}=20)$ & $12,75(3,582)$ & $12,10(3,093)$ & $0,126^{\mathrm{a}}$ \\
\hline Intervensi $(\mathrm{n}=20)$ & $12,50(2,685)$ & $4,25(1,333)$ & $0,000^{\mathrm{b}}$ \\
\hline $\boldsymbol{P}_{\text {value }}$ & $0,804^{\mathrm{c}}$ & $0,000^{\mathrm{d}}$ & P value $<0,05$ \\
\hline
\end{tabular}

Keterangan : a, b : Paired T-test, c,d : Independent T-test

Berdasarkan hasil uji Independent T-test menunjukan bahwa ada pengaruh terapi relaksasi otot progresif terhadap kekuatan otot lanjut usia. Hal ini dibuktikan dengan nilai $p=0,000$ atau $p<0,05$ yang artinya H1 diterima. Berdasarkan hasil uji Independent T-test menunjukan bahwa ada pengaruh terapi relaksasi otot progresif terhadap kualitas tidur lanjut usia. Hal ini dibuktikan dengan nilai $p=0,000$ atau $p<0,05$ yang artinya $\mathrm{H} 1$ diterima.

\section{PEMBAHASAN}

Kekuatan Otot sebelum dan sesudah dilakukan terapi relaksasi otot progresif pada lanjut usia

Hasil uji Independent T-test pada kekuatan otot sebelum dan sesudah dilakukan intervensi didapatkan hasil $p$ value $=0,013$ untuk data kekuatan otot sebelum dilakukan intervensi yang artinya tidak ada perbedaan yang signifikan antara kekuatan otot sebelum diberikan terapi relaksasi otot progresif pada kelompok kontrol dan kelompok intervensi. Sedangkan setelah intervensi didapatkan hasil $p$ value $=0,000$ untuk data kekuatan otot sesudah intervensi yang artinya ada 
perbedaan yang signifikan antara kekuatan otot setelah diberikan terapi relaksasi otot progresif pada kelompok kontrol dan kelompok intervensi.

Proses menua dapat menimbulkan berbagai masalah yaitu salah satunya masalah fisik. Semakin lanjut usia seseorang, mereka akan mengalami kemunduran terutama di bidang kemampuan fungsional. Perubahan morfologis yang terjadi pada sistem muskuloskeletal dapat mengakibatkan perubahan fungsional otot yaitu terjadi penurunan kekuatan dan kontraksi otot, elastisitas dan fleksibilitas otot dan daya tahan otot dan tulang (Muhith, 2016).

Hasil tersebut mengalami peningkatan pada kelompok kontrol disebabkan karena adanya aktivitas fisik yang dilakukan oleh sebagian lansia. Aktivitas tersebut seperti, senam, jalan - jalan santai sekitar panti, dan menonton televisi. Terjadinya peningkatkan kekuatan otot lansia pada kelompok intervensi disebabkan selain karena lansia melakukan aktivitas yang sama dengan kelompok kontrol, kelompok intervensi diberikan terapi relaksasi otot progresif yang dapat membuat rileks responden.
Kualitas tidur sebelum dan sesudah dilakukan terapi relaksasi otot progresif pada lanjut usia

Hasil uji Independent T-test pada kualitas tidur sebelum dan sesudah intervensi didapatkan hasil $p$ value $=0,804$ untuk data kualitas tidur sebelum dilakukan intervensi yang artinya tidak ada perbedaan yang signifikan antara kualitas tidur sebelum diberikan terapi relaksasi otot progresif pada kelompok kontrol dan kelompok intervensi. Sedangkan setelah intervensi didapatkan hasil $p$ value $=0,000$ untuk data kualitas tidur sesudah intervensi yang artinya ada perbedaan yang signifikan antara kualitas tidur setelah diberikan terapi relaksasi otot progresif pada kelompok kontrol dan kelompok intervensi.

Perubahan dari aspek fisiologis menyebabkan adanya perubahan fisik pada lanjut usia diantaranya perubahan sistem persarafan (Muhith, 2016). Perubahan sistem persarafan yang terjadi pada usia lanjut yaitu adanya gangguan terhadap kualitas tidur. Gangguan kualitas tidur terjadi akibat adanya perubahan biologis tertentu yang membuat tidur lebih sulit seiring dengan bertambahnya usia,seperti hilangnya kontrol irama sirkardian pada proses tidur (Hidayat \& Ulyah, 2015). 
Terjadinya peningkatan kualitas tidur lansia yang baik pada kelompok intervensi disebabkan karena diberikannya terapi relaksasi otot progresif. Terapi ini dilakukan apabila tidak bisa tidur, karena dengan teknik ini dapat menenangkan pikiran lansia, maka kita dapat menghindari penghamburan tenaga yang tidak perlu dan menyimpannya untuk hal-hal yang diperlukan.

\section{Pengaruh terapi relaksasi otot progresif terhadap kekuatan otot dan kualitas tidur lanjut usia}

Berdasarkan hasil uji Paired T-test pada kekuatan otot terdapat perbedaan yang signifikan antara kekuatan otot sebelum dan sesudah terapi relaksasi otot progresif pada kelompok intervensi karena nilai signifikan yaitu $p<0,05$ artinya $\mathrm{H}_{1}$ diterima berarti ada pengaruh terapi relaksasi otot progresif terhadap kekuatan otot lanjut usia. Untuk beberapa lansia, proses penuaan menjadi sebuah beban.Merekakehilangan kemampuan baik secara fisik, contohnya keterbatasan gerak, maupun psikologis, contohnya depresi atau kerusakan kognitif. Hal ini menyebabkan pula timbulnya gangguan didalam hal mencukupi kebutuhan hidupnya sehingga dapat mengakibatkan ketergantungan yang memerlukan bantuan orang lain (Muhith, 2010).
Terapi relaksasi otot progresif membuat setiap orang lebih mudah untuk meningkatkan kekuatan otot. Lansia dengan kekuatan otot yang menurun sebaiknya memilih jenis terapi yang sebagian besar menggunakan otot-otot besar, dengan gerakan-gerakan ritmis (berirama) dan berkesinambungan. Saat melakukan teknik tersebut responden akan merasakan ketegangan yang dapat melatih otot responden. Berdasarkan hasil uji Paired T-test pada kualitas tidur terdapat perbedaan yang signifikan antara kualitas tidur sebelum dan sesudah terapi relaksasi otot progresif pada kelompok intervensi karena nilai signifikan yaitu $p<0,05$ artinya $\mathrm{H}_{1}$ diterima berarti ada pengaruh terapi relaksasi otot progresif terhadap kualitas tidur lanjut usia.

Seseorang bertambah tua maka kemampuan fisik dan psikisnya perlahanlahan akan mengalami penurunan. Salah satu contohnya yaitu lansia akan mengalami gangguan pemenuhan kebutuhan tidur. Gangguan tidur pada lanjut usia merupakan keadaan dimana seseorang mengalami suatu perubahan dalam kuantitas dan kualitas pola istirahatnya yang menyebabkan rasa tidak nyaman atau mengganggu gaya hidup yang diinginkan(Muhith, 2016). 
Terapi relaksasi otot progresif merupakan suatu terapi yang menjadi solusi terhadap masalah gangguan tidur lansia. Lansia dilatih melakukan terapi relaksasi otot progresif dari gerakan awal sampai akhir, dengan tujuan agar lansia bisa membedakan bagaimana sensasi pada saat otot tegang maupun rileks. Selain itu, lansia juga diminta untuk mengkombinasikan gerakan tersebut dengan nafas dalam, dimana setelah lansia melakukan terapi relaksasi otot progresif, maka tubuh lansia akan terasa rileks dan pikiran menjadi tenang serta nyaman.

\section{KESIMPULAN}

Berdasarkan hasil penelitian dan pembahasan tentang pengaruh terapi relaksasi otot progresif terhadap kekuatan otot dan kualitas tidur lanjut usia, dapat disimpulkan bahwa terdapat perbedaan kekuatan otot antara sebelum dan sesudah dilakukan terapi relaksasi otot progresif pada lanjut usia, terdapat perbedaan kualitas tidur antara sebelum dan sesudah dilakukan terapi relaksasi otot progresif pada lanjut usia, dan ada pengaruh terapi relaksasi otot progresif terhadap kekuatan ototdan kualitas tidurlanjut usia

\section{SARAN}

Penelitian ini supaya menambah bahan referensi bagi Mahasiswa keperawatan dalam pengembangan keilmuan bidang keperawatan gerontik untuk meningkatkan kekuatan otot dan kualitas tidur setelah dilakukan relaksasi otot progresif, Pelayanan kesehatan supaya meningkatkan pelayanan terhadap lanjut usia yaitu memberikan intervensi yang tepat dan dapat diaplikasikan dalam praktek keperawatan yang memberikan dampak efektif dalam meningkatan kekuatan otot dan kualitas tidur lanjut usia, misalnya terapi relaksasi otot progresif, mengatur kenyamanan lingkungan, dll, dan untuk lanjut usia diharapkan hasil penelitian ini dapat dijadikan sebagai salah satu metode alternatif bagi lanjut usia untuk meningkatkan kekuatan otot dan kualitas tidur.

\section{REFERENSI}

Ananda, Irma. P.(2016). Pengaruh Range Of Motion (ROM) Terhadap Kekuatan Otot Pada Lansia Bedrest di PTSW Budhi Mulia 3 Margaguna Jakarta Selatan. Skripsi Sarjana tidak dipublikasikan. Jakarta: Universita Islam Negeri Syarif Hidayatullah.

Arifin, Z.(2011). Analisis Hubungan Kualitas Tidur Dengan Kadar Glukosa Darah Pasien Diabetes Melitus Tipe 2 di RSU Provinsi NTB. Skripsi Sarjana tidak dipublikasikan. Jakarta : Universitas Indonesia. 
Fitriani, H., Achmad.(2017). Pengaruh Intervensi Relaksasi Otot Progresif Terhadap Disminore Primer pada Remaja. Faletehan Health Journal.Vol. 4 No. 3.

Guyton, A. C. and Hall, J. E. (2014).Buku Ajar Fisiologi Kedokteran. 12. Jakarta: EGC.

Harsono. (2007). Kapita Selecta Neurologi. Yogyakarta: GadjahMada University Press.

Hidayat, A.A., danUliyah, M. (2015). Pengantar Kebutuban Dasar Manusia Edisi 2 Buku 2. Jakarta: Salemba Medika.

Kemenkes, RI. (2015). Data dan Informasi 2014.

(Online). (http://www.depkes.go.id/resources Ldownload/pusdatin/profilkesehatan-indonesia/data-daninformasi-2014.pdf, diakses pada tanggal 27 Desember 2017).

Mardjono, M., dan Sidarta, P. (2010). Neurologi Klinis Dasar. Jakarta: Dian Rakyat.

Muhith, Abdul. (2010). Kemampuan Fungsional Lansia di UPT Panti Werdha Majapahit Mojokerto.Hospital Majapabit. Vol 2, No. 2.

Muhith, A., dan Siyoto,S. (2016). Pendidikan Keperawatan Gerontik. Yogyakarta: Andi Offset.

Muhith, A., Yasma, N. A.(2014). Pengaruh Terapi William Flexion Exercise terhadap Nyeri Punggung Bawah pada Lansia di Panti Werdha Mojopahit Mojokerto. Medica Majapahit. Vol 6, No. 1.

Muhith, Abdul. (2013). Stabilitas Tekanan Darah pada Lansia di Panti Werdha Mojopahit Kabupaten Mojokerto. .Medica Majapabit. Vol 5, No. 2.

Muhith, A., Anam, Saiful, M.(2015). Hubungan Kebiasaan Olahraga dengan Kejadian Osteoporosis pada Lansia di Posyandu Lansia Desa Kemantren Kecamatan Tulangan
Kabupaten Sidoarjo. Medica Majapabit. Vol 7, No. 1.

Potter, A., dan Perry, A.G.(2005). Fundamental Keperawatan. Jakarta: EGC.

Siregar, M.H. (2011). Mengenal SebabSebab, Akibat-Akibat, dan Cara Terapi Insomnia. Yogyakarta: Flash Books.

Sumitra, I. N., dan Laraswati, Aa. I.(2014). Faktor Yang Menyebabkan Gangguan Tidur (Insomnia) Padalansia. Jurnal Keperawatan Politeknik Kesehatan Denpasar.

Susilo, H. (2015). Pengaruh Teknik Relaksasi Progresif dengan Musik Keroncong Terhadap Peningkatan Kualitas Tidur Lansia di Panti Wredha Budi Darma. Skripsi Sarjana tidak dipublikasikan. Yogyakarta: Sekolah Tinggi Ilmu Kesehatan Aisyiah.

Tortora, G. J., and Derrickson, B. (2009). Principles Of Anatomy and Physiology. USA : John Wiley and Sons. Inc.

Utomo, B.(2010). Hubungan Anatara Kekuatan Ototdan Daya Tahan Otot Anggota Gerak Bawah dengan Kemampuan Fungsional Lanjut Usia. Tesis Magister tidak dipublikasikan. Surakarta: Universitas Sebelas Maret.

Utomo, B., dan Pudjiastuti, S.S. (2003). Fisioterapi Pada Lansia. Jakarta: Buku Kedokteran EGC.

Utomo, B., dkk. (2012). Peningkatan Kekuatan, Fleksibilitas dan Keseimbangan Otot Lanjut Usia Melalui Senam Mandiri. Jurnal Terpadu Ilmu Kesehatan. Jilid 2, pp. 712.

Wavy, W. W. Y.(2008). The Relationship Between Time Management, Perceived Stress, Sleep Quality and Academic Performance Among University. Tesis Magister not publication. Hongkong: Baptist University. 